\title{
Deconstructing Learners' Choices in Composing the Narrative Essay in Secondary Schools
}

\author{
Mak'obila Laban Adero, Lona Wafula, and Agumba Ndalo
}

\section{ABSTRACT}

This paper evaluated narrative essay writing practices in secondary schools. The major question the paper sought to answer was what choices did secondary school learners make in writing narratives based on their writing skills and competence? This was done through qualitative data in which learners' narrative essays were evaluated to determine how faithful the learners were in sticking to the elements of the narrative. The compositions chosen were solicited from a group of students who had finished their secondary education and were waiting to join tertiary institutions. These students had attended various secondary schools and were thus suitable for the content of this paper as they manifested the different essay writing regimes adopted by different schools. These were compositions which they had written as part of their normal class exercises.

Keywords: narrative essay, choices, writing

\section{INTRODUCTION}

Scholars continuously express interest in English language writing. The secondary school English language syllabus recognizes writing as an integral part of language learning process which is treated both as a skill and a craft that needs to be taught and which is learned through practice. Compartmentalization of the teaching of writing has given rise to various approaches to its teaching which is manifested in the way learners write compositions. With numerous studies having been conducted on the teaching and learning of writing. Evaluating the choices made by learners in the process of writing specific genres is however an area that requires a lot of rigorous study. The decision to study learners compositions based on their secondary school experiences is therefore feasible.

\section{CONTEXT AND BACKGROUND OF THE PAPER}

English is the most commonly used second language in Kenya. It is highly valued given its status as a compulsory subject in secondary schools. Acquiring competence in written English is considered difficult by most learners of English as a second language (Maclntyre and Gardner, 1989; Abdel-Latif, 2007).

Writing is very important to secondary school learners as it prepares them for academic writing, a central medium of communication in tertiary institutions including universities. Basically, the English language syllabus specifies the content of writing that is to be taught at all levels in secondary
Published Online: April 30, 2021

ISSN: $2736-4534$

DOI :10.24018/ejedu.2021.2.2.54

Mak'obila Laban Adero* Moi University, Kenya

(e-mail: Makolabby@yahoo.com)

Lona Wafula

Moi University, Kenya

Agumba Ndalo

Moi University, Kenya

*Corresponding Author schools. The content aims at equipping the learners with the necessary skills to enable them communicate effectively and understand competently written English. Additionally, the syllabus content aims at aiding learners to write different types of texts varied in length on familiar themes and topics. This paper evaluates the ability of secondary school learners integrate all the aspects of writing to compose a common genre of essay writing- the narrative.

\section{RESEARCH PAPER QUESTION}

The main research question of the paper is:

What choices do secondary school learners of English make in narrative writing on the following aspects?

1) The selection of topic

2) The title

3) The audience

4) Making outlines

5) Structure and language of the narrative essay

\section{LITERATURE REVIEW}

Ruszkiewicz and Dolmage (2015) describe narrative writing as writing in which writers describe events, that people want to share in words or other media. Narrative texts are organized according to setting and events leading to a problem and a solution. The main features of writing are thus given as: defined characters, descriptive language, the setting and point of view. These are features which the narrative essay shares with the short story. Consequently, in the 
process of writing the narrative essay learners have to make choices regarding the events to be shared, the characters to be included in the narrative and the point of view from which the narrative is written. Regardless of the choices made, narratives focus on an action which is propelled by characters with names and interesting relationships. The characters engage in believable dialogues. The choice of narrative characters and their actions are designed to make the narrative amusing to read, enlightening and therapeutic.

A narrative writer constructs settings, events and characters which speak both to the narrative and the audience reader who in most cases is unknown.

Sims, Chan and Sethuram (2012) emphasize the centrality of the experience one gains from narrative shared with the audience. The experience determines the purpose, the plot and the message the writer imparts to the reader. Narrative writing therefore, involves critical thinking whereby the essayist intentionally determines the purpose which they wish to share with their audience.

Commentators agree that like with all forms of writing the construction of a narrative is defined by a series of activities aimed at determining the experience to be shared and learned. These steps call into mind the creation of the events and their structure that propel the narrative writing exercise smoothly. The writers engage in activities which begin with the generation of idea and the collection of relevant materials through to the publication and writing of the finished text (Hedge 1988, White and Arndt 1991).

\section{APPROACHES TO TEACHING NARRATIVE WRITING}

\section{A. Product Approach}

Teachers draw from a range of approaches in teaching writing. One such approach that has dominated much of the teaching of writing is the product approach. The product approach is also known as the traditional approach to teaching writing. The product approach emphasizes the written product which becomes the focus of the teacher's emphasis in which they only respond to the finished composition. Teaching writing is regarded as mainly the teaching of the mechanics of writing which include punctuation, spelling and correct usage. The teacher plays a primary role as an examiner (Zamel, 1987). Classroom time chosen for writing is allotted to drills and exercises on mechanics or grammar. It focuses on the final product, the coherent and error-free text (Nunan, 1999). The approach involves building up a list of skills that are needed to acquire before producing texts.

Critics point out that the product approach to teaching writing, leads to loss of creativity as the learners depend on their teachers. Learners become passive listeners most of the time (Ahmad, 2010). The teaching method is mostly teacher centred and the use of lecture is paramount. The approach is blamed for the learner tendency to memorize extracts from texts and recall them when needed. Learners encounter challenges wherever they are given topics which they have previously not practiced.

Product approaches to writing are generally about linguistic knowledge, with attention focused on the appropriate use of vocabulary syntax and cohesive devices
(Pincas, 1982). Learning to write is considered to have four stages, familiarization; controlled writing; guided writing and free writing. The familiarization phase aims at making learners aware of the features of a particular text. At the guided and controlled writing phase the learners practice the skills with increased freedom until they are ready for free writing when they use the writing skill as part of a genuine activity (Ibid).

Generally, product based approaches to teaching writing view writing as mainly concerned with knowledge about the structure of language. Writing development is considered a product of imitating texts which teachers provide.

\section{B. The Process Approach}

Arising from the weaknesses of the product approach is the process approach in which students are encouraged to think, plan search for ideas, develop, organize, review their writing and meet the requirement of both examination and academic life. The teacher's main concern is to help learners develop their ideas and focus less on the product. Learners are trained to focus more on the development of drafts of a text (Nunan, 1999). The students are further encouraged to focus on writing their ideas on paper without minding too much about the correctness of forms.

The process approach mainly focuses on the stages of writing which include planning, drafting, revising and editing (Harmer, 2007). Emphasis is on varied classroom activities which involve multiple stages. Learners are taught strategies which help them to express themselves in writing through writing. Mahon (1992) identifies four interrelated steps which learners experience before the final product is produced. These are: pre-writing, drafting, revising and editing and final writing and publishing.

Pre-writing activities involve teachers eliciting ideas from students and helping organize these using mind maps and visuals. On completion the students write drafts with the assurance from teachers that the drafts are not perfect. While revising and editing, the students are supported to reshape their writing by checking spelling, grammar, punctuation and changing ideas. At the end of the process, the students publish their texts. This is the actual production of the final drafts. Opportunities for sharing these drafts are created.

Generally, process approaches revolve around linguistic skills such as planning and drafting with less emphasis on linguistic knowledge. The stages identified are cyclical in which the learners may return to activities upon dealing with the next. The teacher primarily facilitates learners' writing and provides input which is considered less significant. With this approach the learners develop rather than learn writing skills. Teachers only draw out the potential of the learners which is mostly latent. The process of writing is seen as the same regardless of what is being written and who is writing. The context in which writing takes place is central to the writing process. Contextual elements that writers focus on include the audience, the generation of ideas, the organization of the text and its purpose.

By and large process approaches view writing as primarily an exercise of linguistic skills and its development as an unconscious process which occurs when teachers facilitate writing skills. 


\section{Genre Approaches}

This is a relatively new approach to English language teaching which bears a lot of similarities to the product approach. A genre is a type of text. Genre approaches emphasize the fact that though writing is a predominantly linguistic activity, it varies with the social context in which it is produced (Badger and White, 2000). There are a range of writing that are linked with different situations and social contexts in which learners operate affecting the writing syllabus. Central to any situation in writing is the purpose, since different kinds of writing carry different purposes. Other features of the writing situation that influence the genres of writing include: subject matter, the relationships between the writer and the audience and the pattern of organization. In a typical genre based writing class, are three phases to teaching writing. First, modeling the target genre, exposure to examples of the genre and finally the independent construction phase. The learners work independently to produce text that they set out to.

Regardless of the approach teachers choose to use in the teaching of writing, it is imperative to note that writing involves knowledge about language, knowledge of the context in which writing happens and the skills at play in using language. A writing regime is one in which the learner's potential is drawn out by providing input which learners can respond to.

Badger and White (2000) suggest a writing process in which writing is embedded in a social situation so that a piece of writing achieves predetermined purposes within a situation. Teaching within this approach call for an analysis of the language used in a particular text along with the processes by which text writers produce texts. Teachers then provide sufficient support for learners to identify purpose and related aspects of the context writing.

\section{CHALLENGES OF TEACHING WRITING}

There are many difficulties and problems which the teaching of writing faces within the teaching and learning process. These are positively viewed as challenges as it suggests a positive attitude in teaching the skill. Three main challenges have been identified which learners and teachers are confronted with. These are:

1) Teachers attitude

2) Fixation with the examination performance

3) Teaching large classes

\section{A. Teachers' Attitude}

Dornyei, 2003; Hyland and Hyland, 2001; and William; 2003 identify teachers' attitudes and expectations as important factors in teaching writing in second language classrooms. For example Williams (2003) argues that sound teaching methods could fail to produce significant progress in performance if the teachers do not believe that they can make a difference in the classroom and or view students as having little or no competence. To be effective teachers must feel good about teaching and about students and believe that they can influence student learning (Proctor, 1984). The relationship between attitude and performance has been viewed as mutual with each factor affecting the development of the other. Second language acquisition literature supports the relationship between attitude towards language and language achievement (Masgoret and Gardner, 2003). Scholars associate attitude with cognitive affective and behavioural components (Enden, 1991). The cognitive aspect involves beliefs and perceptions about the objects or situations related to the attitude. The affective relates to the feelings and emotions that one has towards an object. The behavioural component means that certain attitudes tend to prompt someone to adopt particular behaviours. All these types of attitudes are interactive in a non-linear form. The cognitive impacts the behavioural and they both influence the affective element and they can swap their roles.

The relationship between attitude and writing is profound. Writing attitude is an affective disposition which involves how the act of writing makes the author feel. Writing attitude is effective in improving or obstructing writing achievement. This paper acknowledges that teachers' attitudes may affect their strategies in teaching writing in English. These could be manifested in the choices learners make while writing essays more so, narratives.

\section{B. Fixation with Examination Performance}

Testing influences teaching and learning. Examinations emphasize memorization of facts. This influences methods of teaching and learning. The high stakes nature of much of testing particularly at secondary school confirms that the curriculum conforms to the examination system. This affects the culture of teaching where students' fear of exams have given rise to incidences where teachers teach to the test (Herrera, 1992).

Exams influence not only the agenda of teachers but the students' parents and the school administrators' as well Broad expectations are held about students' success in the final examination. Teachers teaching style tend to be geared towards serving success in exams. In most cases learners and teachers do not target the development of writing skills, but how to get high score irrespective of teaching and learning.

\section{Teaching Large Classes}

Teaching large classes is in many ways a challenge to teaching. Managing students poses difficulties when teaching large classes. Similarly, teacher-student relationship is negatively affected. The use of time for planning, marking and assessment is equally problematic. It is equally difficult to motivate and involve students' interests in large classes (Ballantyne et al, 2000). Large classes affect the interaction between teachers and students and could affect collaborative tasks within the classroom. Teachers point out that collaborative activities are difficult to design in their classrooms because of the big number of students, so they have to lecture most of the time. In narrative writing pedagogy large classes could positively aid the writing process. Learners could share numerous and varied ideas and exciting life experiences. This stimulates the learners and enlivens those parts of the lesson where the learners can discuss and learn from each other (Sarkisian, 2010).

\section{METHODOLOGY AND PARTICIPANTS}

To acquire comprehensive information about the choices that high school learners made regarding narrative writing qualitative data collection method was used. This mainly 
involved an analysis of ten narrative essays of ten students who had finished secondary level.

The participants were randomly selected from a group of students within Eldoret town in Kenya. Incidentally, the ten students had attended different high schools and were waiting to join tertiary institutions. Of the ten, six were boys and four were girls. Since the participants were high school leavers it was assumed that they had had sufficient interaction with writing while in high school. Each participant was asked to avail their composition notebooks from which a narrative was picked for analysis.

\section{FINDINGS AND DISCUSSION}

\section{A. Students' Choice of Topics for Narrative Writing}

The choice of topic or subject of narratives posed little challenge to the learners. These had been provided for by the teachers as part of class exercises. The topics varied across the levels but in most cases learners were expected to write about their personal experiences that revolved around:

1) The day they would live to remember

2) First day in secondary school

3) My life as a wreck.

In some cases the teachers asked the learners to write narratives that would complete sentences that the teachers gave. For example there were two interesting such exercises

... I saw a spider rebuilding its web and immediately thought of my own life... boy.

... I concluded that work with no play made Jack a dull

Related to the choice of subject matter was the title. There were cases of learners who creatively worked around the topics given by their teachers to construct memorable titles. Some of the titles were:-

\section{"The Magnetic Pull" \\ "The Rebirth" \\ "My Choice"}

There were few cases in which the learners replicated the assignments given as the titles of their narratives. Such titles left nothing to the imagination and they were mostly wordy and failed to pull readers towards them. For example the following titles were long and simply replicated the assignments:

The day I saw a spider rebuilding its web

Work which gives no room for play.

In selected cases there were compositions without titles. The tendency by the learners to restrict themselves to the topics that were provided by the teachers limited their choices and could be the result of the failure to write beyond the dictates of the teacher. This is a result of learners interpretation of writing as a curriculum activity which is undertaken for the sake of examinations and not for the joy of it. Such an approach to selection of writing subjects limits practice and inhibits their competence.

\section{B. Choice of Thesis in Learners' Narratives}

In a narrative the thesis statement contains the lesson learned from the event or series of events written about. This equally explains the purpose of writing the narrative. Thesis writing basically demands the writer to explain the significance of the choice of experience. The construction of a thesis or purpose statement demands that writers figure our why the events in the story written about stood out. Similarly, one could also think about what readers could learn from the writer's experience. This failure by all learners to clearly state their purpose could be attributed to the approaches to teaching writing. It is possible teachers do not emphasize the centrality of writing beyond the experiences. Learners are taught to write correctly without thought for deeper expression. Thinking about thesis goes deeper than merely relieving experiences on paper.

The narratives analysed did not have a clear thesis. All the narratives only related the events as they unfolded even when it was obvious that the topic invited the writer to share what they would have learnt from their narratives.

\section{PLANNING FOR NARRATIVE ESSAYS}

Whether writing about steps, phases or stages in the writing process, writers such as Ruszkiewicz and Dolmage (2015) and Sims, Chan and Sethuram (2012) all consider decisions made by writers in the process of writing at each stage as critical. It is the extent to which a narrative writer succeeds in weaving together various activities at each stage in the writing process that defines the ability to communicate clearly, accurately and appropriately. Out of the activities that define this success is brainstorming.

It was not apparent from the learners narrative the extent to which they brainstormed over their selected topics before writing. This is because in most classes brainstorming is conducted orally and is not easy to translate into writing. It is also possible that writing down the mechanics of a brainstorm session has not been considered as being part of the essay. However, all the compositions displayed outlines which were crossed through. This is because the outlines are not considered as part of the composition and in most cases act as memory guides. Even then the outlines were not informative enough. There were cases in which the students only gave the sketches as the outlines:

Introduction - What I am going to write

Body - How I have been away from

home

Conclusion - I return home.

Compared to yet another composition which had the following elements:

Introduction - What are the characters?

- Where are they?

- What is their problem?

There were several narratives that were more informative. For example:

Introduction - Characters- Granny, my cousin,

I

- $\quad$ Setting- Granny's house, Christmas day

- $\quad$ Conflict - Granny's parking

Body - Granny's appearance

-Granny making chocolate

-Granny with water color tools

-My cousin's and my intervention

Conclusion - Granny aging

-We prepare the chocolate

-Granny and us celebrate

It is possible to conclude then the writer outlines reflected brainstorms that the students engaged in. 
All the outlines reflected emphasis placed on the functions of an outline by different teachers. Whereas an outline provides the reader with the plot of the narrative as driven by the conflict in the narrative, this is treated casually. Sketchy could be the result of the experience of the learners in writing. They were yet to reach a level where they could construct outlines that provided all the information about their narratives. This might have also been due to the space available and the dilemma which most learners have regarding whether the outline is part of the narrative and therefore add up to the word count. Learners viewed outlines more as plans without details. Apparently, school writing does not to emphasize the depth of outlines. It could also be possible that narratives do not render themselves easily for outline writing. The students' outlines failed to state the purpose, describe the details of the setting and gave scanty details of what the narrative contained.

Equally hard to determine from the written narrative essay are the other elements of planning, namely revising and editing. Practically these aspects demand that the writers check out their constructions, choice of words, clarity of information and appropriateness. Where these are done plenty of time is needed which under normal circumstances is not possible especially when the writing is timed. School writing hardly gives premium to these aspects since they are never marked. Learners end up not giving them consideration in their writing. Secondary school learners therefore treat writing as an activity that is geared towards the product even when they have provided beautiful outlines.

\section{Structuring the Narrative Essay}

The compositions were varied in their structure. All were written in the past tense which is common with narratives because they relay events that have already taken place. The narratives mostly adopted a chronological structure in which the events were narrated in the sequence in which they happened. Similarly, the narratives were mostly written from the point view of the writer in which the first person narrative technique was predominat. This approach enhanced believability of the incidences because the students were writing about their own experiences.

The events written about were those that stood out. These included names of places and people; the time which was given in terms of the days of the week, the month, the year or the season. These were the most memorable and worth sharing.

Some of the narratives adopted complimentary modes of delivery in which the narrations were interpreted with flashes of description, disclosure and explanation.

I watched closely grandmother finish her beautiful memorable colouring of the petals of the flower. She absentmindedly dipped the brush with heavy paint into her bowl of porridge. She lifted her paint water to her mouth. Suddenly, she realized her mistake before the murky liquid touched her lips. I realized sadly that age was fast working on granny's abilities.

Such detailed descriptions were however rare. There was little variety occasioned by the dictates of school writing in which exercises emphasize common place narration told in correct grammar. It could also be true that in teaching emphasis is placed on the feature that define given genres of writing so that learners hardly think of integrating difficult modes by coloring the narratives with beautiful descriptions, memorable quotes and interesting explanations.

The simple structures were characterized by repetition, limited number of characters and common place events. This was obviously the result of the emphasis placed on correctness and strict adherence to word limits.

\section{E. Language Use in Learners Narratives}

All learners demonstrated a good mastery of English language. The tips of sentences constructed were a mixture of simple, compound and complex sentences. The choice of words in the narratives were relevant and appropriate to the experiences that narratives relayed. The use of idiomatic expressions and figures of speech majorly the use of similes was profound. There were common expressions that cut across the compositions. The following expressions stood out.

1) A red letter day

2) To cut a long story short

3) The coast was clear

The incidence of common idiomatic expressions and figures of speech could be attributed to the common recommended books that learners use while in school. Both set books and reference books are recommended by the Kenya Institute of Curriculum Development and it is possible then that learners have mastered the use of common expressions from these books.

Learners' correct grammatical constructions is a reflection of the emphasis that teachers place on correct usage of structures. High scores are awarded to compositions with least errors. The learners thus attempt to compose error free narratives.

\section{F. Choice of Audience}

Do learners give a thought to the readers of their narratives? How do they determine their readers' needs and how is this catered for in their narratives?

Badger and White (2000) consider a narrative audience to be wide cutting across all spheres. They attribute this to the fact that people generally enjoy stories for various reasons. It is therefore critical that writers pay attention to their audience, their interests and needs.

The learners hardly gave a thought to their audience. This should have been obvious that they were writing for the teachers who would read and award their narratives grades. Once the teacher is satisfied with the quality of their writing the rest did not matter. The teacher is therefore the examiner and the audience. It is possible that teachers hardly emphasize the place of the audience in the narrative since this hardly counts in exams. Ruszkiewicz and Dolmage (2015) propose several ways in which writers could focus on the audience which could apply to writing class assignments These include capitalizing on ideas that could be less entertaining if presented formally and looking at oneself as the target audience. To them readers care about people. Narratives should thus focus on people with names and clearly defined relationships whereas most of the narratives had defined characters, the learners tended to slow down their interaction by describing them instead of presenting them through their actions and speech. This explains wh the 
narratives were devoid of dialogues that would vary the modes of presentation. One positive aspect with the compositions was the choice of name which were common and memorable. It gave the impression that the readers wanted easily identity with such names as the principal, teacher Ohiang' etc.

\section{CONCLUSIONS AND RECOMMENDATIONS}

From the selected compositions the paper made the following conclusions:

Teaching of narrative writing affected the choices that learners made in the course of writing.

It is clear that teachers emphasize features of specific genres of writing which learners produce in their writing. The teaching is more examination oriented in which case the learners concentrate on aspects of correctness which would earn them good grades. Learners are restricted in their writing thus are unable to experiment with novel modes. It is equally desirable that competence in writing is equated to the good grade that one gets.

It is possible for teachers to prepare learners for writing as a skill by encouraging writing workshops. It is also possible to emphasize the hidden feature of narrative writing in the course of teaching. These are the features which this paper has dwelt on.

\section{REFERENCES}

Ahmed, A.H. (2010). The EFL Writing Difficulties of Egyptian Student Teachers of English: Implication for Essay Writing Curriculum and Instruction. Unpublished $\mathrm{PhD}$. University of Exeter.

Badger, R., and White, G. (2000). A process Genre Approach to Teaching: ELT Journal Vol 54/2 Oxford University Press.

Ballantyne, R., Borthwick, J. and Parker, J. (2000). Beyond Student Evaluation of Teaching: Identifying and Addressing academic staff development needs. Assessment and Evaluation in Higher Education. 25(3), 221-236.

Boote, R. (1964). English Language for Sixth Forms: Neil and Company: Edinburgh

Dornyei, Z. (2003). Questionnaires in Second Language Research; Construction, Administration and Processing. Lawrence Earlbaum Associates, Inc.

Flowerdew, J.(1993). An Educational or Process Approach to Teaching of Professional Genres: ELT Journal 47/4: 305-316.

Ford, M. (1960). Techniques of Good Writing. Toronto: The Book Society of Canada.

Harmer, J. (2007). How to Teach English: Essex Person- Longman.

Hartman, H.J. (2001a). Developing Students' Metacognitive Knowledge and Skills. In H.J Hartman (Ed.), Metacognition in Learning and Instruction: Theory, Research and Practice (PP, 33-68). Boston: Kluwer Academic.

Herrera, L. (1992). Science of Schooling: Inside a Girls School in Cairo. Cairo Papers in Social Science, 15, Monograph 1.

Hyland, F. and Hyland, K. (2001). Sugaring the Pill: Praise and Criticism in Written Feedback. Journal of Second Language Writing, 10, 185-212.

Jordan, R.R. (1997). English for Academic Purposes: A Guide and Resource Book for Teachers. Cambridge: Cambridge University Press.

MacIntyre, P.D. and Gardner, R.C. (1989). Anxiety and Second Language Learning: toward a theoretical clarification. Language Learning, 32, 251-275.

Mackey, A. and Gass, S. (2005). Second Language Research: Methodology and Design. London: Routledge.

Macmillan English (1988). Thinking and Writing Process. New York: Scribler Laidlaw.

Mahon, T. (1992). From Sentence to Story: A Process Approach to the Development of Composition Skills in Primary School. In Lau, M. and Murphy, M. (Eds). Developing Writing: Purposes and Practices. Hong Kong: Institute of Language in Education, Education Department.

Mosgoret, A.M., and Gardner, R.C. (2003). Attitudes, Motivation and Second Language Learning, 53, 123-163.
Murray, D.M., (1980). Writing as Process. How Writing finds its own meaning. In T.R. Donovan and B.W. McClelland (Eds). Eight Approaches to Teaching Composition (PP 3-20). Urbana, In National Council of Teachers of English.

Nunan, D. (1999). Second Language Teaching and Learning. Boston: Heinle and Heinle Publishers.

Pincas, A. (1982b). Writing in English. London: Macmillan

Proctor, C. (1984). Teacher Expectations: A Model for School Improvement: Elementary School Journal 84(4), 469-481.

Ruszkiewicz,J.J. and Dolmage, J.T., (2015). How To Write Anything: A Guide and Reference with Readings. New York; Bedford St. Martins.

Sarkisian, E. (2010). Working in Groups. Derek Book Center for Teaching and Learning: Harvard University. Available at: http://isites.harvard.edu/html/icb.topic58474/wiginNo.html

Sims, M. (2009). The Write Stuff. New Jersey: Prentice Hall.

Sims, M., Chan, W. and Sethuram, P. (2012). The Write Stuff. Thinking Through Essays. Ontario; Pearson.

Taylor, C. (2019). How to Write a Narrative. https://www.wikihow.com/write-a-Narrative. Downloaded on 4/18/2020 11:21.

Wekden, a.L. (1991). Learner Strategies for Learner Autonomy. London Prentice Hall.

Williams, J.D. (2003). Preparing to Teach Writing: Research, Theory and Practice. London: Routledge.

Zamel, V. (1987). Recent Research in Writing Pedagogy. TESOL Quarterly, 21(4).

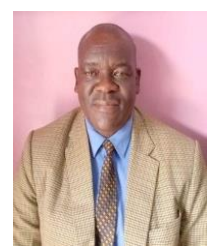

Dr. Mak'obila Laban Adero, is a Language Educator at Moi University Kenya. $\mathrm{He}$ is a Doctoral Degree holder in English Language Education of Moi University where he studied for his Masters and Undergraduate respectively. He has widely published in the areas of English language and teacher education, teacher pedagogy and communication. Currently he co-ordinates language education programmes and post graduate studies in the Department of Curriculum Instruction and Educational Media at Moi University's School of Education.

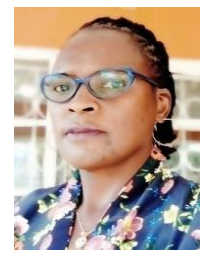

Dr. Lorna Wafula, is a teacher educator at Mo University (Kenya). She holds a $\mathrm{PhD}$ in English Education. Dr. Wafula is serving as a coordinator, School of Education, Eldoret West Campus. She has also served as a Coordinator, School of Education, Kitale Campus and a Deputy Coordinator, Eldoret West Campus. Dr. Wafula is a supervisor to a number of masters' students in the School of Education. She has, alone and jointly published widely. She is a reviewer with the International Journal of Research and Scientific Innovation (IJRSI). She is a member of several professional bodies which include: Kenya Association of Educational Administration and Management (KAEAM), The Kenya Association of English Language Educators and Researchers (ASELER) and Language Association of Eastern Africa (LAEA). Prior to joining Moi University, Dr. Wafula worked as an Assistant Lecturer at Rongo University. She also has more than ten years of working experience as a senior teacher of English Language and Literature at high School level in Kenya. Dr. Wafula has been a principal researcher in multi-educational issues. However, her key research interests are in Pedagogies in English Language and Literature Education.

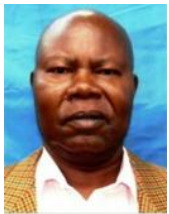

Dr. Agumba Ndalo, teaches History Education in the School of Education at Moi University. He has published extensively in teacher education and pedagogy and sits on many educational boards. Dr. Agumba is a graduate of Moi University where he attained his undergraduate, master's and Doctoral degrees. He is Dean designate of the Faculty of Education Koitalel Samoei University College Eldoret Kenya. 